\title{
Records of Southern Sea Lion (Otaria flavescens) (Mammalia: Carnivora: Otariidae) and Total Mercury (THg) Levels in Muscle Tissue of a Specimen on the East Coast of Rio de Janeiro State, Southeastern Brazil
}

\author{
Marcelo Tardelli Rodrigues ${ }^{1,2 *}$, Eduardo Barros Fagundes Netto3, Rodrigo Cumplido1, \\ Ubirajara Gonçalves de Melo Junior¹, David Braga Quintanilha', Eliane Teixeira Mársico4, \\ Micheli da Silva Ferreira Ascoli ${ }^{4}$, Carlos Frederico Marques Guimarães ${ }^{4}$
}

\footnotetext{
${ }^{1}$ Programa Associado de Pós-Graduação em Biotecnologia Marinha (PPGBM), Instituto de Estudos do Mar Almirante Paulo Moreira (IEAPM) and Universidade Federal Fluminense (UFF), Arraial do Cabo-RJ, Brazil

${ }^{2}$ Instituto Federal de Educação, Ciência e Tecnologia Fluminense (IFF)/Campus Cabo Frio, Laboratório de Ecotoxicologia e Microbliologia Ambiental (LEMAM), Cabo Frio-RJ, Brazil

${ }^{3}$ Instituto de Estudos do Mar Almirante Paulo Moreira (IEAPM), Departamento de Oceanografia, Divisão de Oceanografia Biológica, Arraial do Cabo-RJ, Brazil

${ }^{4}$ Universidade Federal Fluminense (UFF), Centro de Ciências Médicas (CCM), Faculdade de Veterinária (CMV),

Departamento de Tecnologia de Alimentos (MTA), Laboratório de Controle Físico-Químico de Alimentos (LCFQA),

Niterói-RJ, Brazil

Email: *orcinusorca86@gmail.com
}

How to cite this paper: Rodrigues, M.T., Netto, E.B.F., Cumplido, R., de Melo Jr., U.G., Quintanilha, D.B., Mársico, E.T., da Silva Ferreira Ascoli, M. and Guimarães, C.F.M. (2019) Records of Southern Sea Lion (Otaria flavescens) (Mammalia: Carnivora: Otariidae) and Total Mercury (THg) Levels in Muscle Tissue of a Specimen on the East Coast of Rio de Janeiro State, Southeastern Brazil. Open Access Library Journal, 6: e5290.

https://doi.org/10.4236/oalib.1105290

Received: February 25, 2019

Accepted: March 22, 2019

Published: March 25, 2019

\begin{abstract}
This study aims to present records of southern sea lions (Otaria flavescens) on the coast of Arraial do Cabo, located on the east coast of Rio de Janeiro State, southeastern Brazil, and information on the levels of total mercury (THg) found in muscle tissue of a specimen collected in the study area. Between July 2003 and February 2017, 5 occurrences of southern sea lions were recorded in the study area. Four of these records were of live animals, while one was of a carcass in advanced state of decomposition. In relation to the concentrations of $\mathrm{THg}$ found in the muscle tissue of the analyzed individual, they ranged from 0.047 to $0.067 \mathrm{mg} / \mathrm{kg}$, with a mean value found of $0.057 \mathrm{mg} / \mathrm{kg}$, a standard deviation of 0.010 and a coefficient of variation of $17.5 \%$.
\end{abstract}

\section{Subject Areas}

Animal Behavior, Zoology 
Copyright $\odot 2019$ by author(s) and Open Access Library Inc.

This work is licensed under the Creative Commons Attribution International License (CC BY 4.0).

http://creativecommons.org/licenses/by/4.0/

\section{Keywords}

Records, Mercury, Southern Sea Lion

\section{Introduction}

The southern sea lion (Otaria flavescens Shaw, 1800) is a marine mammal that belongs to the Order Carnivora, Suborder Pinnipedia, and to the Family Otariidae (fur seals and sea lions, also known as otariids) [1] [2]. The species occurs in the Atlantic and Pacific Ocean, on the coast of South America [1] [2] [3]. On the coast of Argentina, Otaria flavescens is the most common pinniped [3] and the most abundant otariid, widely distributed from Mar del Plata, in the province of Buenos Aires $\left(38^{\circ} 12^{\prime} \mathrm{S}, 57^{\circ} 33^{\prime} \mathrm{W}\right)$, to the province of Tierra del Fuego $\left(52^{\circ} 27^{\prime} \mathrm{S}\right.$, $69^{\circ} 25^{\prime} \mathrm{W}$ ) [4]. The species also occurs on the coast of Peru, on the west side (margin) of South America, southern Brazil, and the Falkland Islands (Malvinas Islands) [1] and reproduces on islands of Uruguay, Argentina, Falkland Islands, Peru, and Chile [5]. However, there are occasional records of the species in Colombia [6] [7], Galapagos Islands [8], and even on the coast of Panama in Central America [9].

According to [5], southern sea lions do not present migratory movements. However, males perform significant seasonal movements almost every year during the winter and spring months [10] [11].

In Brazil, although there are no reproductive colonies of any species of pinniped, many specimens of fur seals, sea lions and, eventually, elephant seals and Antarctic seals, reach on the coast of Rio Grande do Sul State between the months of autumn and spring, favored in their post-reproductive displacements mainly by the cold Falkland Current [11] [12] [13] [14]. According to [13], some species, such as the South American ones, have a defined seasonality. On the coast of Rio Grande do Sul, the two most frequent species are the southern sea lion (Otaria flavescens) and the South American fur seal (Arctocephalus australis) [15]. These two species, besides having reproductive colonies nearby, located in Uruguayan waters, use two concentration sites in the winter in Rio Grande do Sul: Ilha dos Lobos, in the city of Torres, and the Molhe Leste of Lagoa dos Patos, in the city of São José do Norte [5] [10] [16] [17] [18] [19], both defined as "Conservation Units" in the category of "Wildlife Refuge" [15].

In Rio de Janeiro State, the species has already been recorded on the coast of cities of Rio de Janeiro [20], Macaé [12], and Armação dos Búzios [21]. The northernmost record of $O$. flavescens in Brazil is one specimen in Bahia State, in Salvador (approximately $13^{\circ} \mathrm{S}$ ) [22].

The objective of this study is to present records of southern sea lions (Otaria flavescens) on the coast of Arraial do Cabo, a small city located on the east coast of Rio de Janeiro State, and information on levels of total mercury in muscle tis- 
sue of an individual collected in the area in question.

\section{Materials and Methods}

\subsection{Study Area}

The region of Arraial do Cabo ( $\left.22^{\circ} 58^{\prime} 79^{\prime \prime} \mathrm{S}, 42^{\circ} 01^{\prime} 34^{\prime \prime} \mathrm{W}\right)$, located on the east coast of Rio de Janeiro State, southeastern Brazil (Figure 1), presents a warm and humid climate, with an average temperature of $25^{\circ} \mathrm{C}$ in the summer and between $17^{\circ} \mathrm{C}$ and $23^{\circ} \mathrm{C}$ in the winter, and rainfall reduced in relation to the adjacent regions [23]. These climatic characteristics are related to the local geography, distance of Serra do Mar from the costline, presence of Lagoa de Araruama, and upwelling phenomenon [24]. The region of Arraial do Cabo presents two important characteristics: a unique oceanic projection in relation to the coast, which makes it one of the most advanced Brazilian coast points towards the sea and the presence of the upwelling phenomenon, which causes the rise of deep cold waters rich in nutrients, which generates a high primary productivity and, consequently, benefits the entire marine trophic structure, besides fishing [25] [26] [27].

On the Brazilian coast, marine extractive reserves have been created with the purpose of protecting traditional fishermen's populations and the marine resources from which these fishermen draw their own livelihood [28] [29]. Created by the federal government in 1997, the Arraial do Cabo Marine Extractive Reserve (Reserva Extrativista Marinha de Arraial do Cabo/RESEXMAR AC) located on the east coast of Rio de Janeiro State, about $180 \mathrm{~km}$ from the city of Rio de Janeiro and $14 \mathrm{~km}$ from Cabo Frio, comprises a fishing area extending from east to west, between Praia de Massambaba, in the city of Araruama, and Praia do Pontal, in the city of Arraial do Cabo, on the border with Cabo Frio, including

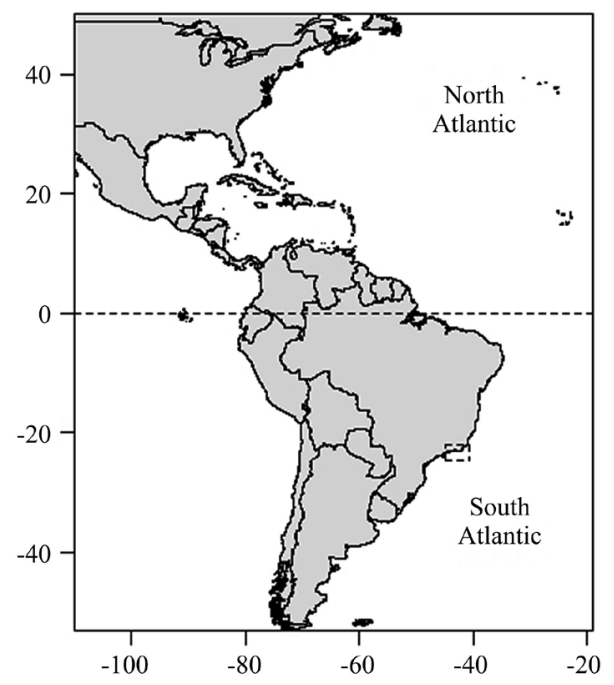

Figure 1. Brazilian coast, with an emphasis on the east coast of Rio de Janeiro State, where the region of Arraial do Cabo (Latitude: $23^{\circ} \mathrm{S}$ - Longitude: $42^{\circ} \mathrm{W}$ ) is located. Source: Prepared by the author using the software R. 
a marine area three nautical miles from the coast of Arraial do Cabo, toward the sea, between the coordinates $22^{\circ} 56^{\prime} 57^{\prime \prime} \mathrm{S}$ and $42^{\circ} 04^{\prime} 19^{\prime \prime} \mathrm{W}$, corresponding to a total area of 56,769 hectares of water line [28] [30].

\subsection{Beach Monitoring}

Between January 2003 and December 2015, 1386 days of beach monitoring were carried out in the coast of Cabo Frio and Arraial do Cabo, totaling 3835 hours of activities. This monitoring had as an objective to record the occurrence of live marine mammals, mainly living cetaceans, along the coast, to rescue alive stranded animals, and to collect dead stranded animals for study.

\subsection{Sample Collection}

A southern sea lion specimen was found dead (with missing body parts), in advanced state of decomposition, at Prainha, in Arraial do Cabo, in February 2017. At the time, about $300 \mathrm{~g}$ of muscle was collected, removed from the anterior dorsal region of the body, for mercury analysis.

\subsection{Samples Preparation}

At the collection site, the muscle sample was wrapped in a Coleman brand thermal box, with $63 \mathrm{~cm}$ long, $36 \mathrm{~cm}$ wide and capacity of storing 100 liters and then transported to the Laboratório de Ecotoxicologia e Microbiologia Ambiental (LEMAM) of the Instituto Federal de Educação, Ciência e Tecnologia Fluminense (IFF), Campus Cabo Frio, where it was immediately washed with distilled water and then weighed in a Mars brand precision analytical balance, model AW220 (g). The muscle was divided into three smaller pieces (triplicate), taken from the central and lateral sides of the larger sample, which were homogenized and then weighed into pieces containing approximately $0.30 \mathrm{~g}$ ( $0.25 \mathrm{~g}$ in average) each. Shortly thereafter, the muscle pieces were again washed with distilled water and then stored in zipped polyethylene bags (zip-lock bags), washed previously by being soaked overnight, in a Merck brand (Darmstadt, Germany) nitric acid $\left(\mathrm{HNO}_{3}\right)$ solution, of the highest quality degree (Suprapur), to 65\% and then rinsed with ultra-pure water. After the storage of the samples, they were stored in a freezer at a temperature of $0^{\circ} \mathrm{C}$. After three months of storage, the samples were transported in a thermal box filled with scaled ice at a temperature of $0^{\circ} \mathrm{C}$ to $6^{\circ} \mathrm{C}$, by land, to the Laboratório de Controle Físico-Químico de Alimentos (LCFQA) of the Departamento de Tecnologia de Alimentos (MTA) of the Faculdade de Veterinária (CMV) of the Centro de Ciências Médicas (CCM) of the Universidade Federal Fluminense (UFF), located in the city of Niterói-RJ, where they remained frozen in a freezer under the same temperature for about a month until the moment of the analysis.

\subsection{THg Determination}

There are reliable and highly sensitive analytical techniques that are used for the 
determination of mercury $(\mathrm{Hg})$. One of the most popular techniques is Atomic Absorption Spectrometry (AAS) [31] [32]. The AAS is a technique for determining elements based on the absorption of radiation by free atoms [33]. Its fundamental principle involves the measurement of the absorption of the electromagnetic radiation intensity coming from a source of primary radiation by gaseous atoms in ground state. This technique uses this phenomenon for the quantitative determination of elements (metals, semimetals and some nonmetals) in a wide variety of samples, such as biological (tissues and fluids), environmental (soils, sediments, waters, and plants), geological, and technological materials, as well as food and several others [34].

For the determination of total mercury $(\mathrm{THg})$ in the biological samples, the Thermal Decomposition Amalgamation Atomic Absorption Spectrometry (TDA AAS) technique was used, according to the methodology described by [33]. This technique can be used for the analysis of solid and liquid samples [33]. The equipment used was the Direct Mercury Analyzer DMA-80, manufactured by Milestone (Sorisole, Italy). The DMA- 80 produces accurate results across a wide dynamic range in a variety of different matrices and allows the total determination of $\mathrm{Hg}$ without the need for previous digestion of the sample, with an analysis time of approximately 5 minutes and detection limit (DL) of $1.5 \times$ $10^{-6} \mu \mathrm{g} / \mathrm{kg}$ of $\mathrm{THg}$ (wet weight/w.w.). Its operation is based on thermal decomposition, which releases all the metal from the sample. The products released in the combustion are transported to the catalytic part of the furnace where the interferents are eliminated. Then, the amalgamation of the metal occurs, which is captured selectively. The amalgamation furnace is heated and the mercury is quickly released and dragged by the gas to the spectrophotometer. The results were expressed as milligrams of mercury per kilograms of sample $(\mathrm{mg} / \mathrm{kg})$.

\subsection{Validation of the Analytical Method for the Determination of THg}

The analytical method was validated based on the evaluation of the following parameters: linearity of the analytical curves, sensitivity (detection limits-DL and/or quantification limits-QL of the method), and precision (through the use of/using "Certified Reference Materials/CRMs" and recovery tests).

Two analytical curves are required to work with the DMA-80, since there are two absorption cells in the equipment. The first working range, relating to the absorbance of cell 1, includes responses from $0.01 \mathrm{ng}$ to about $20.00 \mathrm{ng}$ of mercury (low range). The second working range, relating to the absorbance of cell 2 , includes responses from about $20.00 \mathrm{ng}$ to $1000 \mathrm{ng}$ of mercury (high range). A calibration curve for ultratraces is also possible at the beginning of cell 1 [33]. In this study, linearity was evaluated through the regression coefficients of the analytical curves obtained for the two mercury analyzing cells. Two concentration ranges were used: the first (low range) from 0.5 to $20 \mu \mathrm{g} \cdot \mathrm{kg}^{-1}$, and the second 
(high range) of 20 to $1000 \mu \mathrm{g} \cdot \mathrm{kg}^{-1}$. For both concentration ranges, satisfactory values were observed, with $\mathrm{r}^{2}>0.999$.

The sensitivity (detection limits-DL and/or quantification limits-QL) of the method was evaluated by the analysis of a sample of fish (little tunny/Euthynnus alletteratus, predatory species inclined to present high levels of mercury contents) with low mercury content, by performing six analytical repetitions. The values obtained in the repetitions presented similarity, since no significant difference in the results was evidenced. The Direct Mercury Analyzer DMA-80 has a detection limit (DL) of $1.5 \times 10^{-6} \mu \mathrm{g} / \mathrm{kg}$ of THg.

The precision was evaluated by analyte recovery tests, which consists of "fortification" of the sample, that is, the addition of solutions (with different concentrations of the analyte of interest), and then, in the determination of the concentration of the analyte added. The average percentage of total mercury (THg) recovery in the certified samples was $92 \%$, showing that there was no significant difference between the certified values and those measured for THg.

For the validation of the $\mathrm{THg}$ determination method in biological samples, the verification of its analytical precision was also carried out through the analysis of "Certified Reference Materials (CRMs)", in this case the NRCC-DORM-2 Dogfish muscle and the NRCC-DORM-4 Fish Protein, produced and certified by the National Research Council of Canada (NRCC), located in the city of Ottawa, Canada, which allowed to verify the accuracy of the method used. The National Research Council of Canada (NRCC) produces "Certified Reference Materials" (CRMs) for biological tissues, isotopic standards, natural waters, sediments, supplements, and natural health products. The samples were treated and analyzed under the same conditions as the samples of the "Certified Reference Materials (CRMs)". Analyzes were also validated by international intercalibration methods [35] [36].

\subsection{Statistical Analysis of Results}

For the statistical analysis of results, simple descriptive statistics, resulting from the use of statistical functions from MICROSOFT EXCEL ${ }^{\circledR} 2007$ program, was used.

\section{Results}

Between July 2003 and February 2017, five occurrences of southern sea lions (Otaria flavescens) were recorded on the coast of Arraial do Cabo, a small city located on the east coast of Rio de Janeiro State (Table 1). The year with the highest number of records was $2013(\mathrm{n}=2)$, followed by 2003, 2008, and 2017, each with only one record (Table 1$)$. The highest number of records $(n=3)$ occurred in July, that is, in the winter (Figure 2). According to [5], southern sea lions do not migrate. According to [10] and [11], males perform significant seasonal movements almost every year during the winter and spring months. Southern sea lions reach on the coast of Rio Grande do Sul State between the months of autumn and spring, favored in their post-reproductive displacements 
Table 1. Southern sea lion (Otaria flavescens) records on the coast of Arraial do Cabo, east coast of Rio de Janeiro State, southeastern Brazil, between 2003-2017.

\begin{tabular}{|c|c|c|c|c|c|}
\hline $\mathrm{N}^{\bullet}$ & Date & $\begin{array}{c}\text { Location } \\
\text { Geographical coordinates }\end{array}$ & Sex & $\begin{array}{l}\text { Age } \\
\text { range }\end{array}$ & $\begin{array}{l}\text { Total } \\
\text { length }\end{array}$ \\
\hline 01 & 03/07/2003 & $\begin{array}{l}\text { Praia Grande, Arraial do Cabo-RJ } \\
22^{\circ} 58^{\prime} 35^{\prime \prime} \mathrm{S}, 42^{\circ} 01^{\prime} 57^{\prime \prime} \mathrm{W}\end{array}$ & $\hat{0}$ & A & $2.43 \mathrm{~m}$ \\
\hline 02 & $15 / 07 / 2008$ & $\begin{array}{l}\text { Prainha, Arraial do Cabo-RJ } \\
22^{\circ} 57^{\prime} 42^{\prime \prime} \mathrm{S}, 42^{\circ} 01^{\prime} 14^{\prime \prime} \mathrm{W}\end{array}$ & $\hat{0}$ & A & $2.48 \mathrm{~m}$ \\
\hline 03 & 08/07/2013 & $\begin{array}{l}\text { Praia Grande, Arraial do Cabo-RJ } \\
22^{\circ} 58^{\prime} 06^{\prime \prime} \mathrm{S}, 42^{\circ} 02^{\prime} 09^{\prime \prime} \mathrm{W}\end{array}$ & $\hat{0}$ & A & $2.50 \mathrm{~m}$ \\
\hline 04 & $04 / 10 / 2013$ & $\begin{array}{l}\text { Porto do Forno, Arraial do Cabo-RJ } \\
22^{\circ} 58^{\prime} 16^{\prime \prime} \mathrm{S}, 42^{\circ} 00^{\prime} 55^{\prime \prime} \mathrm{W}\end{array}$ & $\hat{0}$ & A & $2.35 \mathrm{~m}$ \\
\hline 05 & $06 / 02 / 2017$ & $\begin{array}{l}\text { Prainha, Arraial do Cabo-RJ } \\
22^{\circ} 57^{\prime} 23^{\prime \prime} \mathrm{S}, 42^{\circ} 01^{\prime} 37^{\prime \prime} \mathrm{W}\end{array}$ & --- & --- & --- \\
\hline
\end{tabular}

Age range: newborn $(\mathrm{NB}) /$ neonate $(\mathrm{N})$, pup $(\mathrm{P})$, juvenile $(\mathrm{J})$, adult $(\mathrm{A})$, undefined $(\mathrm{UN}) /$ undetermined (UN).
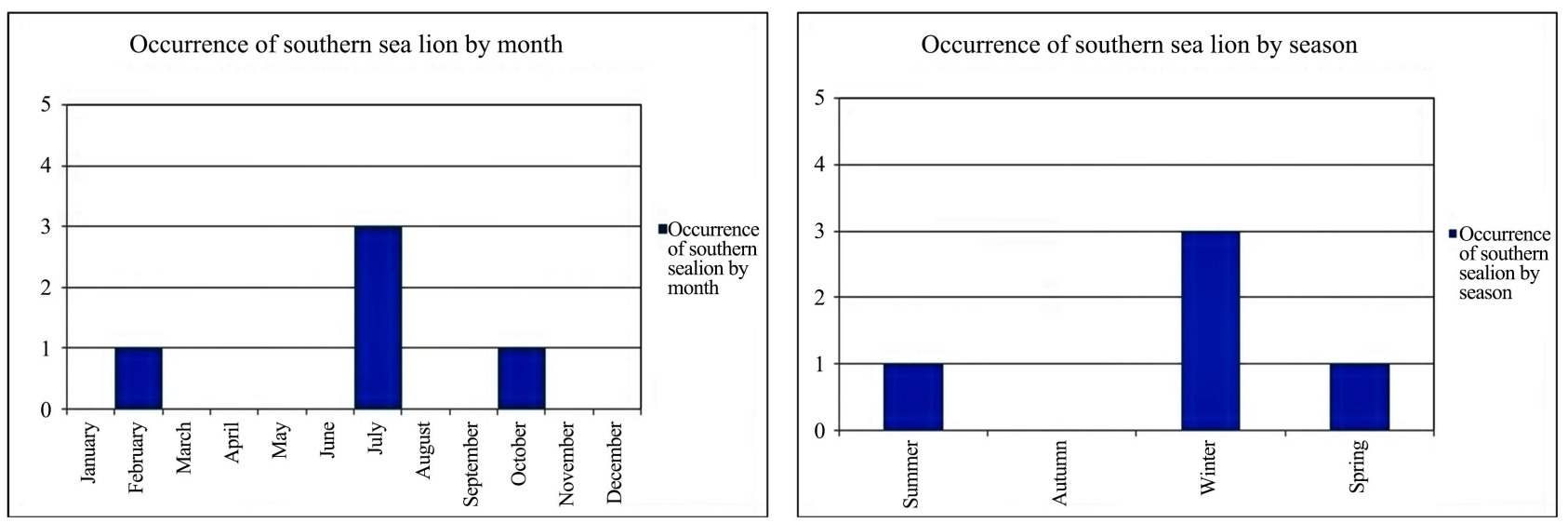

Figure 2. Occurrence of southern sea lion (Otaria flavescens) on the coast of Arraial do Cabo-RJ, by month and season.
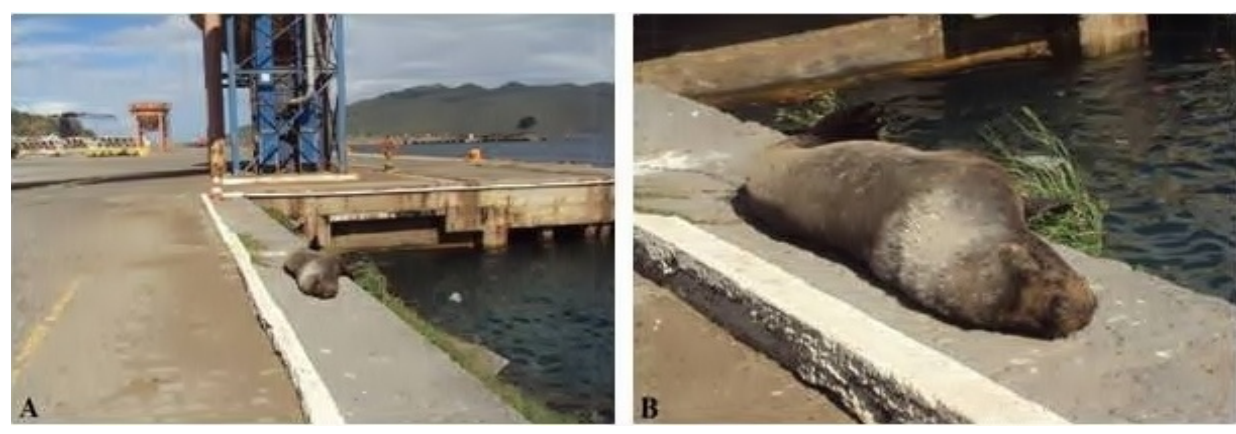

Figure 3. (A and B): Specimen of southern sea lion (Otaria flavescens) at Porto do Forno, in Arraial do Cabo-RJ, on October 4, 2013. Source: Marcelo Tardelli Rodrigues.

mainly by the cold Falkland Current [11] [12] [13] [14].

Four of these records were of live animals (Figure 3(A) and Figure 3(B)), while one was of a carcass of a specimen in an advanced state of decomposition. All live animals observed were adult males, ranging in length from 2.35 to 2.50 
m. According to [1], adult males are unmistakable, having a mane of long, coarse, and erectile hair, extending from forehead to shoulders and from chin to midchest. Most males darken with age, becoming brownish orange, although the mane and underparts often remain lighter. Males sometimes have a darker face, giving them a slightly masked appearance, and adults of both sexes can present pale gold coloration. In relation to length and weight, according to [1], males reach $2.60 \mathrm{~m}$ in length and weigh up to $350 \mathrm{~kg}$, while females reach $2.20 \mathrm{~m}$ in length and weigh up to $144 \mathrm{~kg}$. According to [2], males reach $2.50 \mathrm{~m}$ in length and weigh up to $350 \mathrm{~kg}$, while females reach $1.90 \mathrm{~m}$ in length and weigh up to $145 \mathrm{~kg}$.

The live specimens observed were apparently in good health and presented no injuries, scars, and/or marks on the body that indicate interactions with anthropic activities, such as interactions with fishing nets, which may cause the entanglement of these animals and, in most cases, lead them to death.

In relation to the specimen found dead, in an advanced state of decomposition, it was collected and measured. However, it was not possible to accurately determine its overall length due to the lack of parts of its body. For the study of total mercury concentrations ( $\mathrm{THg}$ ) in the muscular tissue of the individual in question, about $300 \mathrm{~g}$ of muscle were collected, which were later divided into three smaller pieces and analyzed in triplicate by the technique of Thermal Decomposition Amalgamation Atomic Absorption Spectrometry (TDA-AAS) with the Direct Mercury Analyzer DMA-80. Results obtained were expressed in wet weight (w.w.).

Concentrations of total mercury $(\mathrm{THg})$ of $0.047,0.057$, and $0.067 \mathrm{mg} / \mathrm{kg}$ were detected in the muscle of the analyzed specimen, with a mean value of 0.057 $\mathrm{mg} / \mathrm{kg}$, standard deviation of 0.010 , and a variation coefficient of $17.5 \%$. The mean value \pm standard deviation $(0.057 \pm 0.010)$ found was compared with the mean \pm standard deviation of "Certified Reference Materials (CRMs)", in this case, the NRCC-DORM-2 Dogfish muscle $(4.64 \pm 0.26) /\left(\mu \mathrm{g} \cdot \mathrm{g}^{-1} / \mathrm{mg} \cdot \mathrm{kg}^{-1}\right)$ and the NRCC-DORM-4 Fish Protein $(0.410 \pm 0.055) /(\mathrm{mg} / \mathrm{kg})($ Table 2$)$.

Table 2. Comparison between total mercury ( $\mathrm{THg}$ ) values in Certified Reference Materials (CRMs) and the values obtained in biological samples (muscle tissue) analyzed in this study.

\begin{tabular}{cccc}
\hline $\begin{array}{c}\text { Analyte/ } \\
\text { Metal analyzed }\end{array}$ & $\begin{array}{c}\text { Certified Reference Materials (CRMs) } \\
\text { for trace metals in biological tissues }\end{array}$ & $\begin{array}{c}\text { Certified } \\
\text { values }\end{array}$ & $\begin{array}{c}\text { Values obtained in } \\
\text { this study }\end{array}$ \\
\hline $\begin{array}{c}\text { Mercury } \\
(\mathrm{Hg})\end{array}$ & $\begin{array}{c}\text { NRCC-DORM-2 Dogfish Muscle } \\
\text { National Research Council of Canada } \\
\text { (NRCC) Ottawa, Canada }\end{array}$ & $\begin{array}{c}4.64 \pm 0.26^{\mathrm{abc}} \\
\left(\mu \mathrm{g}^{-1} / \mathrm{mg}^{-1} \mathrm{~kg}^{-1}\right)\end{array}$ & $\begin{array}{c}\mathbf{0 . 0 5 7} \pm \mathbf{0 . 0 1 0} \\
(\mathrm{mg} / \mathrm{kg})\end{array}$ \\
$\begin{array}{c}\text { Mercury } \\
(\mathrm{Hg})\end{array}$ & $\begin{array}{c}\text { NRCC-DORM-4 Fish Protein } \\
\text { National Research Council of Canada } \\
\text { (NRCC) Ottawa, Canada }\end{array}$ & $\begin{array}{c}0.410 \pm 0.055^{\mathrm{d}} \\
(\mathrm{mg} / \mathrm{kg})\end{array}$ & $\begin{array}{c}\mathbf{0 . 0 5 7} \pm \mathbf{0 . 0 1 0} \\
(\mathrm{mg} / \mathrm{kg})\end{array}$ \\
\hline
\end{tabular}

Analyte: A chemical substance or component in a sample which is the subject of analysis in a test or experiment. ${ }^{a}$ Bustamante et al. (2003) [37]. ${ }^{b}$ Branco et al. (2004) [38]. 'Carvalho (2007) [39]. ${ }^{\mathrm{d}} \mathrm{NRCC}$ (2013) [40]. 


\section{Discussion}

The southern sea lion (Otaria flavescens) occurs from southern Brazil to southern Argentina along the Atlantic Ocean, and around the Chilean and Peruvian coasts along the Pacific Ocean [41] [42], although it has also been reported in Colombia [6] [7], Galapagos Islands [8], and even on the coast of Panama in Central America [9]. According to [5], the species does not carry out migratory movements. However, according to [10] and [11], males perform significant seasonal movements during the winter and spring months, almost every year. According to [12], [13] and [14], O. flavescens, as well as other species of pinnipeds, carry out post-reproductive displacements, favored mainly by the cold Falkland Current (Malvinas Current).

In southern Brazil, most occurrences of southern sea lions were reported from September to November during their non-breeding distribution [21]. On the coast of Rio Grande do Sul State, O. flavescens is considered the most frequent pinniped [5] [16] [18] [10]. However, on the coast of Rio de Janeiro State, the species is rarely observed, it has been reported in only three occasions so far, in published records about to the observations of the species on an unconfirmed date at Praia Vermelha (Urca), in the city of Rio de Janeiro-RJ [20], on 24 December 1975, in the city of Macaé-RJ [12], and on 14 January 2006, at Praia da Ferradura, in the city of Armação dos Búzios-RJ, that is, in later spring and early summer, respectively [21]. It is believed that southern sea lion individuals that inhabit the Brazilian coast originate from the breeding colony of Uruguay, where there are about 12,000 seals [43].

According to [44] and [10], the northern dispersion pattern of $O$. flavescens is related to suitable prey in southern Brazilian waters. Still according to the authors, this dispersion occurs especially with adult males and sub-adults which could travel long distances far from the breeding colonies. According to [10], foraging activities conducted near the breeding ground could result in a collapse due to competition for food, especially for females and juveniles that need to forage and store energy to maintain their parental care. Studies conducted in southern Brazil have shown that southern sea lions observed in this region feed mainly on demersal fish of the Family Scianidae (e.g. banded croaker/Paralonchurus brasiliensis, king weakfish/Macrodon ancylodon, striped weakfish/Cynoscion striatus, and whitemouth croaker/Micropogonias furnieri) and Family Trichiuridae (largehead hairtail/ Trichiurus lepturus) [45] [46].

Marine mammals are top predators in marine food webs and, for this reason, generally present high levels of heavy metals in their muscle and organs [47] [48]. The levels of these metals in each species are related to their eating habits and geographical distribution [3]. According to the authors, coastal species usually present higher levels than oceanic species. Still according to the authors, the diet is the main source of heavy metals in marine mammals and prey preference may influence the amount of these metals in these animals. It is known that cephalopods and fish are natural accumulators of mercury [49] [50]. As a 
consequence, when feeding on these animals, marine mammals are exposed to these heavy metals [3]. According to the authors, this characteristic, associated with the longevity and diversified foraging ecology of these animals, places them as an interesting group to study heavy metals.

Although heavy metal studies have been conducted in several marine mammal species, information on Hg in southern sea lions is still scarce [51] [52], due to the fact that these animals are protected by law in several countries, which restricts their collection and study, and allows only the collection of specimens, usually dead, in accessible areas [3]. It is known, for example, that food is the main source of metals in southern sea lions and that specific prey can contribute to the contamination of their natural predators by specific metals [3]. Studies conducted by [5] [53] [54] and [55], reported that the species feeds on fish, crustaceans, and mollusks (cephalopods).

Bioaccumulation of heavy metals by $O$. flavescens can affect its behavior or survival. However, there isn't enough information in the literature on the contamination of the species by these metals yet [3].

\section{Conclusions}

Due to the fact that there are no reproductive colonies of southern sea lions in Brazil, the occurrence of the species on the Brazilian coast and, consequently, on the coast of Rio de Janeiro State, between autumn and spring months, is related to seasonal movements of adult and sub-adult males during the period that corresponds to their non-reproductive distribution. On the east coast of Rio de Janeiro State, $O$. flavescens records are rare and occurred in the summer (January and February), winter (July), and spring (October). The presence of the species in spring and summer (periods that correspond to the beginning and peak of the upwelling phenomenon, respectively), in the study area, may be related to the search for food (foraging) and possible feeding, because in two separate occasions specimens were observed briefly moving very close to large shoals of little tunny (Euthynnus alletteratus) and chasing a specimen of dolphinfish (Coryphaena hippurus).

In relation to the concentrations of $\mathrm{Hg}$ found in the analyzed individual, it is known that the main route of absorption of this element in marine vertebrates is through feeding. Pinnipeds can be used as environmental sentinels because they can accumulate small or large amounts of different pollutants in their tissues and organs, as well as indicators or bioindicators of the health of coastal ecosystems and oceans.

\section{Acknowledgements}

We thank the researchers and collaborators of the Grupo de Estudo e Pesquisa de Cetáceos de Arraial do Cabo (GEPEC Arraial do Cabo) for the shared information, Gilliatt de Lima Moreira Neto for the revision of the English version of the article, two anonymous reviewers for the important suggestions and critiques 
of the original manuscript, and the Coordenação de Aperfeiçoamento de Pessoal de Nível Superior (CAPES)/(Process No. 1724814) and Conselho Nacional de Desenvolvimento Científico e Tecnológico (CNPq)/(Process No. 133877/2017-5) for the financial support.

\section{Conflicts of Interest}

The authors declare no conflicts of interest regarding the publication of this paper.

\section{References}

[1] Jefferson, T.A., Leatherwood, S. and Webber, M.A. (1993) FAO Species Identification Guide: Marine Mammals of the World. United Nations (UN), Food and Agriculture Organization of the United Nations (FAO), United Nations Environment Programme (UNEP), Rome, $328 \mathrm{p}$.

[2] Monteiro-Filho, E.L.A., Oliveira, L.V., Monteiro, K.D.K.A., Filla, G.F., Quito, L. and Godoy, D.F. (2013) Guia Ilustrado de Mamíferos Marinhos do Brasil. Instituto de Pesquisas Cananéia (IPeC), Projeto Boto-cinza, São Paulo, 108 p.

[3] Gerpe, M., Rodríguez, D., Moreno, V., Bastida, R. and Aizpún, J. (2007) Cooper, Zinc, Cadmium, and Mercury in Southern Sea Lions (Otaria flavescens) from Argentina. Aquatic Mammals, 33, 223-228. https://doi.org/10.1578/AM.33.2.2007.223

[4] Bustos, R.L., Daneri, G.A., Volpedo, A.V., Harrington, A. and Varela, E.A. (2012) The Diet of the South American Sea Lion (Otaria flavescens) at Río Negro, Patagonia, Argentina, during the Winter-Spring Period. Iheringia (Série Zoologia), 102, 394-400. https://doi.org/10.1590/S0073-47212012000400005

[5] Vaz-Ferreira, R. (1982a) Otaria flavescens (Shaw), South American Sea Lion. In: Food and Agriculture Organization of the United Nations (FAO) and United Nations Environment Programme (UNEP), Mammals in the Seas. Small Cetaceans, Seals, Sirenians and Otters, United Nations (UN), Food and Agriculture Organization of the United Nations (FAO), FAO Fisheries Series, United Nations Environment Programme (UNEP), Rome, 5, 477-495.

[6] Mora-Pinto, D.M., Muñoz-Hincapié, M.F., Mignucci-Giannoni, A.A. and Acero-Pizarro (1995) Marine Mammal Mortality and Strandings along the Pacific Coast of Colombia. Reports of International Whaling Commission, 45, 427-429.

[7] Capella, J.J., Flórez-González, L., Falk-Fernández, P. and Palacios, D.M. (2002) Regular Appearance of Otariid Pinnipeds along the Colombian Pacific Coast. Aquatic Mammals, 28, 67-72.

[8] Wellington, G.M. and de Vries, T.J. (1976) The South American Sea Lion, Otaria byronia, in the Galapagos Islands. Journal of Mammalogy, 57, 166-167. https://doi.org/10.2307/1379520

[9] Mendez, E. and Rodriguez, B. (1984) A Southern Sea Lion, Otaria flavescens (Shaw) Found in Panama. Caribbean Journal of Science, 20, 105-108.

[10] Rosas, F.C.W., Pinedo, M.C., Marmontel, M. and Haimovici, M. (1994) Seasonal Movements of the South American Sea Lion (Otaria flavescens, Shaw) off the Rio Grande do Sul Coast, Brazil. Mammalia, 58, 51-59. https://doi.org/10.1515/mamm.1994.58.1.51

[11] Oliveira, L.R., Danilewicz, D., Marins, M.B., Moreno, M.B.I. and Caon, G. (1999) Patterns of Occurrence of Pinnipeds along the Southern Brazilian Coast. 13th Biennial Conference on the Biology of Marine Mammals, Wailea, 8 November-3 December 1999, 139. 
[12] Pinedo, M.C. (1990) Ocorrência de pinípedes na costa brasileira. Garcia de Orta, 15, 37-48.

[13] Simões-Lopes, P.C., Drehmer, C.J. and Ott, P.H. (1995) Nota sobre os Otariidae e Phocidae (Mammalia: Carnivora) da costa norte do Rio Grande do Sul e Santa Catarina, Brasil. Biociências, 3, 173-181.

[14] Oliveira, L.R., Arias-Schreiber, M., Meyer, D. and Morgante, J.S. (2006) Effective Population Size in a Bottlenecked fur Seal Population. Biological Conservation, 131, 505-509. https://doi.org/10.1016/j.biocon.2006.02.017

[15] Rocha-Campos, C.C. and Câmara, I.G. (2011) Plano de Ação Nacional para Conservação dos Mamíferos Aquáticos: Grandes Cetáceos e Pinípedes. Série Espécies Ameaçadas No. 14, Ministério do Meio Ambiente (MMA), Instituto Chico Mendes de Conservação da Biodiversidade (ICMBio), Brasília, 156 p.

[16] Gliesh, R. (1925) A fauna de Torres. Revista de Engenharia de Porto Alegre, 10, 253-354.

[17] Vaz-Ferreira, R. (1982b) Arctocephalus australis (Zimmerman), South American Fur Seal. In: Food and Agriculture Organization of the United Nations (FAO) and United Nations Environment Programme (UNEP), Mammals in the Seas. Small Cetaceans, Seals, Sirenians and Otters, United Nations (UN), Food and Agriculture Organization of the United Nations (FAO), FAO Fisheries Series, United Nations Environment Programme (UNEP), Rome, Vol. 5, 497-508.

[18] Rosas, F.C.W. (1989) Aspectos da dinâmica populacional e interações com a pesca do leão-marinho-do-sul, Otaria flavescens (Shaw, 1800) (Pinnipedia, Otariidae) no litoral sul do Rio Grande do Sul, Brasil. MSc Dissertation, Fundação Universidade Federal do Rio Grande (FURG), Rio Grande, 88 p.

[19] Silva, K.G., Estima, S.C., Barbosa-Filho, R.B. and Monteiro, D.S. (2002) Status de conservação dos pinípedes no litoral do Rio Grande do Sul, Brasil, em 2000 e 2001. 10 Reunión de Trabajo de Especialistas en Mamíferos Acuáticos de América del Sur (RT) y $4^{\circ}$ Congreso de la Sociedad Latinoamericana de Especialistas en Mamíferos Acuáticos (SOLAMAC), Valdivia, 115-116.

[20] Carvalho, C.T. (1975) Ocorrência de mamíferos marinhos no Brasil. Boletim Técnico do Instituto Florestal, 16, 13-32.

[21] Moura, J.F., Di Dario, B.P. and Siciliano, S. (2011) Occurrence of Pinnipeds on the Coast of Rio de Janeiro State, Brazil. Marine Biodiversity Records, 4, 1-10. https://doi.org/10.1017/S1755267211000030

[22] Castello, H.P. (1984) Registros del elefante marino, Mirounga leonina (Carnivora, Phocidae), en las costas del Atlantico sur occidental fuera del area de cria. Revista del Museo Argentino de Ciencias Naturales, 24, 235-243.

[23] Souza, A.B.S. (2007) O incremento dos serviços de recreação e lazer nos meios de hospedagens como possibilidade de melhor desempenho turístico do município de Arraial do Cabo RJ. Graduation monograph, Instituto de Ciências Sociais Aplicadas, Universidade Veiga de Almeida (UVA), Cabo Frio, 86 p.

[24] Araujo, D.S.D. (2000) Análise florística e fitogeográfica das restingas do Estado do Rio de Janeiro. PhD Thesis, Instituto de Biologia, Universidade Federal do Rio de Janeiro (UFRJ), Rio de Janeiro, 176 p.

[25] Valentin, J.L. (1994) A ressurgência-Fonte de vida dos oceanos. Ciência Hoje, 18, 18-25.

[26] Valentin, J.L. (2001) The Cabo Frio Upwelling System, Brazil. In: Seeliger, U. and Kjerfve, B., Eds., Coastal Marine Ecosystems of Latin America, Springer-Verlag, Berlin, 97-105. https://doi.org/10.1007/978-3-662-04482-7_8 
[27] Silva, G.L., Dourado, M.S. and Candella, R.N. (2006) Estudo preliminar da climatologia da ressurgência na região de Arraial do Cabo, RJ. 14th Congresso Brasileiro de Meteorologia, Florianópolis, 27 November-1 December 2006, 1-11.

[28] Silva, P.P. (2004) From Common Property to Co-Management: Lessons from Brazil's First Maritime Extractive Reserve. Marine Policy, 28, 419-428.

https://doi.org/10.1016/j.marpol.2003.10.017

[29] IBAMA (2007) Instituto Brasileiro do Meio Ambiente e dos Recursos Naturais Renováveis. Áreas protegidas do Brasil 4: Áreas aquáticas protegidas como instrumento de gestão pesqueira. Ministério do Meio Ambiente (MMA), Instituto Brasileiro do Meio Ambiente e dos Recursos Naturais Renováveis (IBAMA), Secretaria de Biodiversidade e Florestas, Núcleo da Zona Costeira e Marinha, Brasília, 261 p.

[30] Seixas, C.S. (2008) Co-Managing a Complex Commons: The Case of a Marine Protected Area Established along a Coastal Urban Setting in Brazil. 12th Biennial Conference of the International Association for the Study of Commons-Governing Shared Resources. Connecting Local Experience to Global Challenges, Cheltenham, 14-18 July 2008, 1-21.

[31] Tao, G., Willie, S.N. and Sturgeon, R.E. (1999) Determination of Inorganic Mercury in Biological Tissues by Cold Vapor Atomic Absorption Spectrometry Following Tetramethylammonium Hydroxide Solubilization. Journal of Analytical Atomic Spectrometry, 14, 1929-1931. https://doi.org/10.1039/a906313g

[32] Torres, D.P., Vieira, M.A., Ribeiro, A.S. and Curtius, A.J. (2005) Determination of Inorganic and Total Mercury in Biological Samples Treated with Tetramethylammonium Hydroxide by Cold Vapor Atomic Absorption Spectrometry Using Different Temperatures in the Quartz Cell. Journal of Analytical Atomic Spectrometry, 20, 289-294. https://doi.org/10.1039/b416167j

[33] Torres, D.P. (2013) Mercúrio: Validação de método para determinação em peixe e camarão e avaliação da sua distribuição em tecidos de caranguejos e efeito da presença de selênio. PhD Thesis, Instituto de Química, Universidade Estadual de Campinas (UNICAMP), Campinas, $94 \mathrm{p}$.

[34] Krug, F.J., Nóbrega, J.A. and Oliveira, P.V. (2004) Espectrometria de Absorção Atômica-Parte 1: Fundamentos e atomização com chama. Apostila, São Paulo, 40 p.

[35] Coquery, M., Azemard, S. and de Mora, S.J. (2000) Report on the World-Wide Intercomparison Exercise for the Determination of Trace Elements and Methylmercury in Estuarine Sediment Sample IAEA-405. Report No. IAEA/AL/127 and IAEA/MEL/70, International Atomic Energy Agency (IAEA), Marine Environment Laboratory (MEL), Monaco, $113 \mathrm{p}$.

[36] Wyse, E.J., Azemard, S. and de Mora, S.J. (2004) Report on the World-Wide Intercomparison Exercise for the Determination of Trace Elements and Methylmercury in Estuarine Sediment Sample IAEA-433. Report No. IAEA/AL/147 and IAEA/MEL/75, International Atomic Energy Agency (IAEA), Marine Environment Laboratory (MEL), Monaco, $117 \mathrm{p}$.

[37] Bustamante, P., Garrigue, C., Breau, L., Caurant, F., Dabin, W., Greaves, J. and Dodemont, R. (2003) Trace Elements in Two Odontocete Species (Kogia breviceps and Globicephala macrorhynchus) Stranded in New Caledonia (South Pacific). Environmental Pollution, 124, 263-271. https://doi.org/10.1016/S0269-7491(02)00480-3

[38] Branco, V., Canario, J., Vale, C., Raimundo, J. and Reis, C. (2004) Total and Organic Mercury Concentrations in Muscle Tissue of the Blue Shark (Prionace glauca L.1758) from the Northeast Atlantic. Marine Pollution Bulletin, 49, 871-874. https://doi.org/10.1016/j.marpolbul.2004.09.002 
[39] Carvalho, G.G.A. (2007) Determinação de mercúrio total e inorgânico em tecidos biológicos através de injeção em fluxo acoplado à espectrometria de fluorescência atômica (FI-AFS). $5^{\text {a }}$ Mostra Acadêmica UNIMEP_Educação Brasileira: Extinção ou Sustentabilidade na Universidade e $15^{\circ}$ Congresso de Iniciação Científica UNIMEP, Universidade Metodista de Piracicaba (UNIMEP), Piracicaba, 1-6.

[40] NRCC (2013) DORM-4: Fish Protein Certified Reference Material for Trace Metals. National Research Council of Canada, Certified Reference Materials (CRMs) for Trace Metals in Biological Tissues. https://www.nrc-cnrc.gc.ca/eng/solutions/advisory/crm/certificates/dorm_4.html

[41] King, J.E. (1983) Seals of the World. 2nd Edition. British Museum (Natural History) and Cornell University Press, London, 240 p.

[42] Bastida, R. and Rodríguez, D. (2003) Mamíferos Marinos de Patagonia y Antártida. Vazquez Mazzini, Buenos Aires, 366 p.

[43] Paéz, H. (2006) Situación de la administración del recurso lobos y leones marinos en Uruguay. In: Menafra, R., Gallgo, L.R., Scarabina, F. and Conde, D., Eds., Bases para la conservación y el manejo de la costa uruguaya, Vida Silvestre, Montevideo, 577-584.

[44] Castello, H.P. and Pinedo, M.C. (1977) Os visitantes ocasionais de nosso litoral. Natureza em Revista, 3, 40-46.

[45] Pinedo, M.C. and Barros, N. (1983) Análise dos conteúdos estomacais do leão marinho Otaria flavescens e do lobo-marinho Arctocephalus australis na costa do Rio Grande do Sul, Brasil. Simpósio Latinoamericano sobre Oceanografia Biológica, Montevideo, 25.

[46] Oliveira, L.R., Ott, P.H. and Malabarba, L.R. (2008) Ecologia alimentar dos pinípedes do sul do Brasil e uma avaliacão de suas interacões com atividades pesqueiras. In: Reis, N.R., Peracchi, A.L. and Santos, G.A.S.D., Eds., Ecologia de mamíferos, Technical Books Editora, Rio de Janeiro, 93-109.

[47] Law, R.J. (1996) Metals in Marine Mammals. In: Beyer, W.N., Heinz, G.H. and Redmon-Norwood, A.W., Eds., Environmental Contaminants in Wildlife: Interpreting Tissue Concentrations, CRC Press, Boca Raton, 357-376.

[48] Gerpe, M.S., Rodríguez, D.H., Moreno, V.J., Bastida, R.O. and Aizpún de Moreno, J.E. (2002) Accumulation of Heavy Metals in the Franciscana (Pontoporia blainvillei) from Buenos Aires Province, Argentina. Latin American Journal of Aquatic Mammals, 1, 95-106. https://doi.org/10.5597/lajam00013

[49] Zhang, X., Naidu, S.A., Jewett, J.J., Dasher, S.C. and Duffy, L.K. (2001) Baseline Concentrations of Total Mercury and Methylmercury in Salmon Returning via Bering Sea (1999-2000). Marine Pollution Bulletin, 42, 993-997.

https://doi.org/10.1016/S0025-326X(01)00200-4

[50] Jewett, S.C., Zhang, X., Naidu, A.S., Kelly, J.J., Dasher, D. and Duffy, L.K. (2003) Comparison of Mercury and Methylmercury in Northern Pike and Arctic Grayling from Western Alaska Rivers. Chemosphere, 50, 383-392.

https://doi.org/10.1016/S0045-6535(02)00421-6

[51] Peña, N.I., Moreno, V.J., Marcovecchio, J.E. and Pérez, A. (1988) Total Mercury, Cadmium and Lead Distribution in Tissues of the Southern Sea Lion (Otaria flavescens) in the Ecosystem of Mar Del Plata, Argentina. In: Seelinger, U., Lacerda, L.D. and Patchineelam, S.R. Eds., Metals in Coastal Environments of Latin America, Springer-Verlag, Berlin, 140-146.

[52] Gerpe, M.S. (1996) Distribución y dinámica de metales pesados en mamíferos marinos. PhD Thesis, Universidad Nacional de Mar del Plata, Mar del Plata, 342 p. 
[53] Rivero, L., Bastida, R., Rodriguez, D. and Westergaard, G, (1999) Southern Sea Lion Feeding Habits in Puerto Quequén, Argentina. 8th Congreso Latinoamericano de Ciencias del Mar, 1, 265-266.

[54] Koen Alonso, M., Crespo, E.A., Pedraza, S.N., García, N.A. and Coscarella, M.A. (2000) Food Habits of the South American Sea Lion, Otaria flavescens, off Patagonia, Argentina. Fishery Bulletin, 98, 250-263.

[55] Naya, D.E., Vargas, R. and Arim, M. (2000) Análisis preliminar del león marino del sur (Otaria flavescens) em Isla de Lobos, Uruguay. Boletín de La Sociedad Zoológica del Uruguay, 12, 14-21. 